\title{
Effects of the 1976 Copyright Law
}

\author{
By Anne Kearney \\ Assistant to the University Librarian \\ University of Louisville
}

\section{The impact of the law on reserve room usage and teaching methodology.}

I fall of 1984 the University Libraries at the versity of Notre Dame implemented a new policy on photocopies of copyrighted materials which professors requested for reserve book room usage. After two years of experience with the new policy, a brief survey was done to measure the effectiveness of the reserve staff in dealing with copyright problems and to assess the impact of the new policy on instruction. One result was the discovery of the detrimental effect of the 1976 Copyright Law on faculty teaching methods. ${ }^{1}$

With the tenth anniversary of its implementation in 1978, now is an appropriate time to take a closer look at the impact of this law on the teaching methods used in academe. Numerous articles in this decade have addressed the issue of how the law has affected library reserve operations and some allusions have been made to its effect on faculty. However, nowhere can one find information on whether faculty members have changed their methods of teaching in reaction to reserve book

\footnotetext{
${ }^{\mathrm{l}}$ Richard M. Dougherty, "Editorial: Copyright and the Reserve Book Room," Journal of Academic Librarianship 3 (March 1977): 3. The editor opined that "when the full impact of the new law hits them, some [professors] are sure to bridle at the restraints." Jane Qualls, "The New Copyright Law's Effect on Teachers and Librarians," Tennessee Librarian 31 (Spring 1979): 20-24; Regina Shelton, "Adaptation: A One-Year Survey of Reserve Photocopying," Journal of Academic Librarianship 6 (February 1980): 74-76.
}

room procedures under the new law. This article describes some of the negative results that developed at Notre Dame.

While this report is limited to one institution, the University of Notre Dame, the questions that Notre Dame's experience raises deserve further research. If libraries are to achieve a balance between creators' rights and users' needs without damaging the educational processes, more data will be needed on the effects of the 1976 Copyright Law. It is hoped that this report will be a beginning. While this article will provide some background on how Notre Dame determined its policy for library reserve, it will concentrate on the implementation of the policy and the results two years after it went into effect.

\section{Background}

From 1978 to 1983, Notre Dame based its reserve policy on the ALA model policy and followed many of the guidelines suggested by Charles Martell in a 1978 article. ${ }^{2}$ Faculty members, who put multiple copies of articles or chapters on reserve, had to sign statements that those materials came under the Classroom Copying Guidelines, which the members of the Ad Hoc Committee of Educational Institutions and Organizations on Copyright

${ }^{2}$ Charles Martell, "Copyright Law and Reserve Operations: An Interpretation," C $b R L$ News 39 (January 1978): 1-6. 
TABLE 1

Composition of Reserve Collection 1983-1986

\begin{tabular}{lcccccc}
\hline Year & $\begin{array}{c}\text { Photo- } \\
\text { copies }\end{array}$ & Books & $\begin{array}{c}\text { Total } \\
\text { Items }\end{array}$ & $\begin{array}{c}\text { \% Differ- } \\
\text { ence }\end{array}$ & $\begin{array}{c}\text { Circula- } \\
\text { tion }\end{array}$ & $\begin{array}{c}\text { \% Differ- } \\
\text { ence }\end{array}$ \\
\hline \hline $83-84$ & $60 \%$ & $40 \%$ & 16,668 & NA & 70,522 & NA \\
$84-84$ & $40 \%$ & $60 \%$ & 15,338 & $-8 \%$ & 66,822 & $-4 \%$ \\
$85-86$ & $50 \%$ & $50 \%$ & 14,744 & $-5 \%$ & 62,797 & $-6 \%$ \\
\hline
\end{tabular}

Law Revision had endorsed. ${ }^{3}$ In accordance with Martell's recommendations, all copies, whether the professor originally supplied them or the University Libraries copied them, were returned to the faculty member when they came off reserve.

When the Register of Copyrights published the Report of the Register of Copyrights: Library Reproduction of Copyrighted Works (17 U.S.C. 108), reserve usage remained ambiguous. The question of whether reserve copying came under the classroom guidelines remained unresolved as did the crucial problem of using multiple or single copies for multiple semesters.

\section{Multiple copies and multiple semesters}

There are articles in each discipline which have been so influential on developments in the field that all students should read them at some point in their study. These articles form the core readings that professors use every semester to teach the course. New readings may be added to the list and old readings dropped, but there is usually a substantial number that do not change. Because these readings are continually updated, it is impossible to find them published in any book of readings. Indeed, the only answer to keeping the reading list current is to use photocopies. And the cheapest and most efficient way to make these readings available to the students is to put them on reserve.

Since there is no question that the Copyright Law prohibits the use of single or multiple copies for more than one semester without permission from the copyright holder, it can seriously hamper university libraries in providing the support that the instructional programs require.

\section{New policy}

In the spring semester of 1983 the University Libraries decided to re-evaluate their policy on the use of photocopies of copyrighted materials for reserve readings. This was in response to the newly issued Report of the Register of Copyrights and the lawsuit, Association of American Publishers $v$. New York University. A chief concern was developing a policy that would address the problem of using some materials for multiple semesters.

${ }^{3}$ This Ad Hoc Committee consisted of 39 educational organizations, such as the Authors League of America, the Association of American Publishers, etc.
In preparation for the discussion of these issues, the Reserve staff did a thorough review of the Report of the Register of Copyrights; read articles from library literature; analyzed publications from the Association of College and Research Libraries and the Association of Research Libraries; and consulted the policies of peer institutions. ${ }^{4}$

Because of this research and subsequent discussions with the top management of the University Libraries and the Assistant Counsel of the University, the Libraries adopted a revised and more conservative policy to be carried out over two years. The Libraries published the new policy in September 1983 as a necessary change, to "ensure that the University is in compliance with the copyright law and to preclude legal action against the University." The most pertinent sections of the new policy were: ${ }^{5}$

"Fall 1983-Fall 1984. During the year, the University Libraries will gather information on copyright holders and secure permissions for photocopying. Wherever feasible, the University Libraries will seek to obtain blanket permissions. This may include paying a fee per semester for such permissions where required. In these cases the University Libraries will assume the cost involved for a single copy.

"Fall 1984- . The University Libraries will make one copy at library expense of journal articles and small portions of monographs and other works for use in one semester only; faculty supplied single or multiple copies will not be accepted without the required permission from the copyright holder. The University Libraries will continue to assume the responsibility for obtaining permissions, the cost of such permissions, and the cost for any single copies of required offprints purchased in lieu of permission."

The most important changes in the revised policy were that: 1) copyright permission had to be on

${ }^{4}$ Report of the Register of Copyrights: Library Reproduction of Copyrighted Works (17 U.S.C. 108) (Washington, D.C.: U.S. Copyright Office, 1983); "Model Policy Concerning College and University Photocopying for Classroom, Research and Library Reserve Use," C\&RL News 43 (April 1982): 127-30; Charles Martell, "Copyright-One Year Later: A Symposium," Journal of Academic Librarianship 5 (March 1979): 124-31.

5"'Policy Change: Copyright, Reserve and the University Libraries, “ Notre Dame Report 83/84 (September 9, 1983): 17. 
TABLE 2

Copyright Questionnaire

\begin{tabular}{lcrr}
\hline Question & No. Responses & $\%$ Yes & \% No \\
\hline \hline 1. Change in policy affected teaching style & 117 & 45 & 55 \\
2. Placed fewer copies on reserve & 117 & 68 & 32 \\
3. Reduced amount of required reading & 118 & 35 & 65 \\
4. Reduced amount of supplemental reading & 117 & 46 & 54 \\
5. Required students to buy more books & 114 & 39 & 61 \\
6. Found reserve staff helpful in explaining policy & 100 & 93 & 7 \\
7. Found reserve staff helpful in solving copyright problems & 86 & 88 & 12 \\
\hline
\end{tabular}

file for any use of multiple copies or any use for multiple semesters, and 2) the University Libraries assumed responsibility for obtaining any needed permissions from copyright holders.

\section{Transitional period}

In order to provide for a smooth change from one system to another and to avoid as much disruption to the educational process as possible, the University Libraries scheduled the new policy to go into effect one year from the date it was published. During this period of transition, the staff of the Reserve Book Room did two things.

First, they ascertained the complete citation for every photocopy that had been on reserve in both the current and previous year. Where the citation could not be easily determined from the copy itself, the staff consulted the professor who had placed the photocopy on reserve.

Second, the staff secured permissions by writing to over 800 publishers of periodicals seeking blanket permissions, signing a contract with the Copyright Clearance Center and establishing an account with University Microfilms to take advantage of their reprint service. When an article tended to be used every semester, the staff sought an individual permission from the copyright holder. In cases where more than one chapter of a book was needed, the Libraries purchased multiple copies of the book. If multiple copies were unavailable, the staff wrote the publisher for permission. Sometimes the publishers granted permissions gratis and sometimes Notre Dame had to pay a nominal amount. There were rare occasions when the requested prices seemed exorbitant, but these were usually limited to British publications and prices which the authors set themselves. The importance of the article determined whether the Libraries paid the price or discarded the article, and in all cases, the staff made this determination only after consultation with the professor who had requested the photocopy. ${ }^{6}$

${ }^{6}$ The cost of copyright permissions for the $1984-85$ academic year was $\$ 1,791.45$; in $1985-86$ it was $\$ 1,421.30$.

\section{Composition of the collection}

The effect that the change in policy had on the composition of the collection and the changes in circulation statistics is shown in Table $1 .^{7}$ From 1983 to 1986 the composition of the Reserve collection changed from $60 \%$ photocopies and $40 \%$ books to a 50-50 proportion; the size of the collection dropped by $13 \%$ and the circulation statistics dropped by $10 \%$. It is important to remember that these results were mitigated by extensive communication with the faculty in preparation for the change, including letters, articles in Access, the University Libraries' formal channel of communication with the teaching faculty, as well as formal and informal conversations with faculty members using the reserve facility. ${ }^{8}$ Furthermore, over the summer the Reserve staff sent letters of explanation and welcome packets to all new members of the faculty.

\section{Survey}

In the Spring 1986, the staff mailed a brief survey to all 354 professors who had used the reserve book room facilities during the 1983-1986 academic years. A total of 123 responded for a return rate of $35 \%$. While the main purpose of the questionnaire was to determine how well the reserve staff were responding to faculty needs for reserve materials which were photocopies, the Libraries were also interested in the effect the revised policy had on how these members of the Notre Dame faculty taught their courses. The answers are instructive in showing the stultifying effects of the present law as it applies to higher education.

The instrument, reprinted as Table 2, included seven questions, two of which dealt with the issue of Reserve Book Room staff performance; the other five were concerned with the issues of style of

${ }^{7}$ Anne Kearney, "Annual Report of the Reserve Book Room," University of Notre Dame, 1984-86.

${ }^{8}$ Anne Kearney, "Copyright, Reserve and the University Libraries: Change in Law Forces a Change in Policy," Access: News from the University Libraries 17 (October 1983): 1-2. 
teaching, reserve readings, supplemental readings and additional book purchases.

\section{Results}

The professors gave the reserve staff performance high evaluations: $93 \%$ found the staff helpful in explaining the change in policy; $88 \%$ found the staff helpful in solving copyright problems that they encountered. Significant numbers of those who responded indicated that the new policy had caused them to change their teaching methodology. Forty-five percent said that the change in the way the University Libraries handled photocopies of copyrighted materials had an effect on their style of teaching. Sixty-eight percent had reduced the number of items they placed on reserve, while $35 \%$ reduced the amount of required readings. Further, $46 \%$ also reduced the amount of supplemental readings that they assigned. Thirty-nine percent increased the number of books that their students had to buy for the course.

Some professors, with the anonymity of the survey, admitted to violating copyright law by photocopying materials that had previously been on reserve and passing them out in class. A few were irate that Notre Dame's policy was much more restrictive than that at other universities where they had taught. At those institutions, multiple copies for courses or usage for multiple semesters were the rule. More significant than these comments, however, were others that showed that the law, particularly in regard to multiple copies or multiple se- mesters, simply impeded the education process and caused the students to suffer. Some also commented that the quality of their courses had been significantly lowered because of the constraints of the law.

\section{Conclusions}

That so many faculty members thought the new reserve policy had a negative effect on the instructional process at Notre Dame seems significant. Despite this adverse result, under present interpretations of the Copyright Law, there does not seem to be an alternate position for Notre Dame given its policy of compliance with the law. Nor does there seem to be any additional way for the University Libraries to mitigate the negative effects of such compliance. The small body of existing literature indicates that Notre Dame's experience is not unique. ${ }^{9}$ However, additional research must be done before a final assessment of the Copyright Law's impact on reserve room usage and teaching methodologies can be declared.

\footnotetext{
${ }^{9}$ We do know from Stuart J. Glogoff that at Penn State some professors reported their dissatisfaction. One labeled the law "the most direct assault on the quality of instruction" ever seen; another questioned why Congress was trying to "destroy higher education in America." Stuart J. Glogoff, "Copyright and a Reserve Reading Room: From Menace to Office Routine," Collection Management 3 (Winter 1979): 325 .
}

\section{LSU and five other libraries selected for Nuclear Regulatory Commission project}

The Local Public Documents Room (LPDR) at Troy H. Middleton Library, Louisiana State University, Baton Rouge, has been selected along with five other libraries for a demonstration project that will provide computer terminal access to a portion of the Nuclear Regulatory Commission's (NRC) database. Known as the Document Control System (DCS), the database provides access to publicly available documents on nuclear power reactors, fuel cycle facilities, waste disposal facilities, and all NRC licensed activities. Training for a staff member from each of the six libraries selected was provided at the NRC national office in Bethesda, Maryland.

NRC has provided Middleton Library with a computer terminal, printer, a telecommunications hook-up, microfiche viewer, and microfiche files of all publicly available documents from 1981 to the present. Users may search the database at no charge, then retrieve documents from the microfiche file for viewing and copying.

The purpose of the demonstration project is to determine if this type of access would increase use of the collection. At the end of a six-month period, the project will be evaluated by NRC staff.

The six libraries chosen represent a balance of academic and public libraries and a diverse geographical distribution. All of the libraries currently serve as a LPDR for nuclear power plants located in their respective areas. The LPDR at Louisiana State houses all documents related to the River Bend Nuclear Power Plant, located near St. Francisville, La.

The other libraries are: California Polytechnic University (LPDR for Diablo Canyon Power Plant); State Library of Pennsylvania (LPDR for Three Mile Island Nuclear Station and Peach Bottom Atomic Power Station); Monroe County Library System, Monroe, Mich. (LPDR for Fermi Atomic Power Plant); University of North Carolina at Charlotte (LPDR for McGuire Nuclear Station); and White Plains, N.Y. (LPDR for Indian Point Station). 